2014

\title{
The Language of Secular Islam: Urdu Nationalism and Colonial India
}

Chitralekha Zutshi

College of William and Mary

Follow this and additional works at: https://scholarworks.wm.edu/aspubs

\section{Recommended Citation}

Zutshi, C. (2014). Kavita Saraswathi Datla. The Language of Secular Islam: Urdu Nationalism and Colonial India.

This Article is brought to you for free and open access by the Arts and Sciences at W\&M ScholarWorks. It has been accepted for inclusion in Arts \& Sciences Articles by an authorized administrator of W\&M ScholarWorks. For more information, please contact scholarworks@wm.edu. 
In addition to presenting an analytics of enclave, Bhattacharya's work also extends our understanding of the plantation within colonial and tropical medicine. Over the course of the early twentieth century, the plantation enclave emerged worldwide as one of the sites for the circulation and diffusion of scientific and medical knowledge. As we have learned from the now significant literature on tropical medicine (largely produced in relation to its careers in colonial Africa), tropical medicine was virtually synonymous with colonial medicine. Received wisdom is that the rare medical interventions to which plantation workers were subject were justified on the basis that a labor force had to maintain a basic level of health for the plantation to turn a profit. Yet Bhattacharya shows that plantations did not manifest a functionalist economy of health expenditure under colonialism. Despite the fact that owners and managers were presented with research that suggested that public health investment and infrastructure created and maintained a more productive (and indeed more profitable) workforce, Darjeeling's individual plantations failed to embrace such measures. Although tropical medicine benefited from research in Darjeeling's plantations and among its laborers, the reverse was not true. Nor did plantations come under political pressure by the colonial state to adopt such measures. While the plantation was an economic necessity for the colonial state, the plantation functioned politically as what Bhattacharya calls a ceded territory with a nearly unending supply of cheap labor.

In this impressive book, Bhattacharya demonstrates that, despite the recent fad for celebratory tales of great gushing flows that forge triumphant global connections, it is still possible to publish rigorous analyses of the interruptions over which colonialism and capitalism rode roughshod. She lays open the brutal ties that bound the health of laboring bodies to wider strategic aims of the Indian economy and polity. In the final analysis, Bhattacharya's book suggests that capitalism's growth story in India - that is, the seemingly endless supply of cheap and "replaceable" labor-remains much the same today as it was a century ago.

Sarah Hodges

University of Warwick

Kavita Saraswathi Datla. The Language of Secular Islam: Urdu Nationalism and Colonial India. Honolulu: University of Hawai'i Press. 2013. Pp. xiii, 234. \$49.00.

This book is a refreshing contribution to the scholarship on Muslim politics, nationalism, and language in late colonial India. Through her discussion of language debates in the princely state of Hyderabad in the 1920s and 1930s, which focused on the revival of Urdu as a national language, Kavita Saraswathi Datla reveals the nuances of the negotiations for Muslim cultural and literary recognition in the decades before independence. Urdu emerges in this work not simply as a vehicle for the expression of a politics of identity and difference, but more importantly as a means of shaping the con- versations regarding India's secular national culture and the position of Indian Muslims within it. Datla puts forward a noteworthy definition of secularism for this moment in colonial India, arguing that it was not so much "an approach to politics or a solution to communal problems and rather more a set of projects" (p. 9), all of which attempted to rethink traditional ideas, language, and culture to relocate them within a national vision of India in the future. Urdu nationalism, this book skillfully demonstrates, was a secular and national, not a communal, enterprise.

Scholarship on language and nationalism in colonial India has usually focused on the Hindi-Urdu debates and the script controversies that accompanied them in late nineteenth-century northern India. Not only does this book shift the center of language politics to southern India in a later period, but it also shows that in $\mathrm{Hy}$ derabad, the restoration of Urdu as the medium of instruction at Osmania University was not aimed at asserting its identity as a Muslim language but rather was intended to challenge the position of English as the language of higher education in India. By updating Urdu and rendering it into a modern vernacular, Muslim intellectuals hoped to make the language more accessible and representative than English, thus also asserting its claim as the national language of a united India. They refused to be "minoritized, to be considered anything less than truly national and secular" (p. 15).

The book meticulously details the ways in which this was accomplished as the idea of establishing a vernacular university was discussed in the context of educational reform; as the newly founded Osmania University's medium of instruction, Urdu, and its relationship to other vernaculars was debated; and as the issue of writing the Muslim past into the history of India in university textbooks became part of a larger conversation emphasizing those aspects of Indian Muslim history that could serve a national purpose. In addition, the book records the efforts of Urdu scholars outside the university to bring recognition to Urdu as a secular language that was nonetheless connected to a Muslim past and culture. These efforts foundered at the national level, where Hindi was increasingly presented as the national language of an independent India. Datla illustrates the effects of these national linguistic debates in Hyderabad through a discussion of student protests at Osmania University in the late 1930s and the disputes among advocates of Urdu, Hindi, and of regional vernaculars such as Telugu, Kannada, and Marathi.

Overall, Datla argues persuasively that linguistic arguments were not simply about the position of Urdu but about the definition of the secular. The Muslim intellectuals engaged in them presented alternative visions of the Indian state that were non-majoritarian and recognized Muslim culture as part of the national narrative. The book sheds new light on the two-nation theory that led to the division of British India into India and Pakistan: as an attempt by Muslim politicians to acquire equal, not minority, status for Muslims in an independent India. While Datla provides several examples of 
the encounters between the Hyderabadi movement and the Indian National Congress, especially through the figures of Abdul Haq and Mohandas Karamchand Gandhi, she does not discuss how Hyderabadi intellectuals engaged with the all-India movement for Pakistan and its advocates, such as Muhammad Ali Jinnah. How did regional linguistic movements for Urdu and Muslim cultural recognition such as the one in Hyderabad fit into the overall schema of the politics of the All India Muslim League in the 1920s, 1930s, and 1940s? Such information would have further enriched this wellcrafted book.

\section{Chitralekha Zutshi College of William and Mary}

Ayesha Jalal. The Pity of Partition: Manto's Life, Times, and Work across the Indo-Pakistan Divide. (Lawrence Stone Lectures.) Princeton, N.J.: Princeton University Press. 2013. Pp. xv, 265. Cloth \$27.95, e-book \$27.95.

Ayesha Jalal is an accomplished scholar of modern South Asia who has attracted her fair share of controversy. Her first monograph, Sole Spokesman: Jinnah, the Muslim League, and the Demand for Pakistan (1985), which suggested that Muhammad Ali Jinnah used the concept of Pakistan as a "bargaining chip" with the Indian National Congress, was greeted locally with outrage and denounced for misrepresenting and traducing the contribution of the nation's founder. Her revisiting of the birth of Pakistan fifteen years later in Self and Sovereignty: Individual and Community in South Asian Islam since 1850 (2000) provoked less reaction but still ruffled some feathers by drawing a sharp distinction between personal faith and religion used to bind and mobilize communities to acts of violence, as happened widely and with devastating effect in India in 1947.

The Pity of Partition is Jalal's third excursion into the territory of Partition, but different in focus and conception from her previous outings in that it tracks the journey of just one individual caught up in what the author labels, fairly, the central South Asian event of the twentieth century. Her subject, though, is far from ordinary. Saadat Hasan Manto is considered the finest exponent of the Urdu language since Mirza Ghalib and widely regarded as one of the major short story writers of modern times. He illuminates the Great Divide not only by participating in it-journeying, like thousands of Indian Muslims in 1947, from home and career in what had become, on August 15, the Dominion of India, across the border to make a new life in Pakistan-but by being able to stand back and view his own situation as a refugee from a wider perspective and with the acute insights of a brilliant writer. The book is unusual for a professed work of history in quoting and paraphrasing so profusely from literature, but this is quite a deliberate gambit on Jalal's part. She "strives," Jalal says, "for a new historical methodology that imaginatively connects fictional and historical narratives" (p. xii). Whether the book is actually as innovative as it claims is open to question; however there is no doubt it gains immensely from the richness and rawness of the Manto oeuvre. Manto himself is a riveting character: unruly and restive, anti-authoritarian, egotistical, bohemian, a frequenter of bars and dives, and a drunkard, but also capable of savage self-mockery. Ironically, his story reads a lot like fiction, and it comes as no surprise to learn that his published stories were generally inspired by real events, either from his own life or from the lives of people he met through work or in refugee camps in Pakistan. For instance, his famous short story "Toba Tek Singh," which pillories the capriciousness of the Partition by viewing it through the eyes of a group of "lunatics," was written shortly after Manto emerged from an enforced period of detoxification in the Lahore Mental Asylum.

Jalal chose Manto as a subject in part to rescue him from neglect. While his writings are critically admired, in Pakistan he is officially categorized as a deviant and pornographer, and fifty years after his death none of his stories have yet made it into the state-approved school curriculum. At the same time, recounting the narrative of Manto's growing despair and disillusionment with his own impoverished situation, with the sundering of centuries-old social ties between Hindus and Muslims in the subcontinent, and with the reactionary tendencies emerging in Pakistani Islam allows Jalal to renew her critiques of the politics that led to partition and of the Pakistan state it created. Probably most readers will sympathize with this project. At times, though, it seems to me that Jalal allows her strong identification with Manto (understandable given that he married her mother's elder sister) to blur her historical judgment. For instance she tells us at one point that "Manto realised that no more than a few individuals had been involved in the [partition] mayhem" (p. 144). This is not a conclusion I suspect that would occur to most of the scholars working today on the history of the 1947 holocaust.

That said, Jalal has performed a great service for scholars and the reading public by opening the Manto archive to their gaze. I for one will read Manto's stories, from now on, with added pleasure and comprehension.

IAN COPLAND Monash University

\section{CANADA AND THE UNITED STATES}

Bruce CURTIS. Ruling by Schooling Quebec: Conquest to Liberal Governmentality-A Historical Sociology. Buffalo, N.Y.: University of Toronto Press. 2012. Pp. x, 563. Cloth $\$ 80.00$, paper $\$ 37.95$.

Has Québec developed into a distinct society in North America primarily as a result of its majority Frenchlanguage and Catholic heritage? Or has Québec always been une société normale, understandable in the same ways as other parts of Canada and the United States despite its different linguistic and religious characteristics? This question has played a central role in scholarly debate for many decades now, with ebbs and flows 